\title{
Accounting internationalization and value relevance of accounting earnings in China
}

\author{
(C) Higher Education Press and Springer-Verlag 2009
}

\begin{abstract}
Using financial reports of AB-share listed companies in China from 1996 to 2003, this paper attempts to evaluate the impact of accounting internationalization in China by comparing time serial value-relevance differences between Chinese Accounting Standards (CAS) and International Accounting Standards (IAS). Empirical evidence from relative information content test indicates that unexpected earnings reported under IAS have more information content to A-share investors than those under CAS. However, the relative value-relevance of IAS is weakened through the accounting internationalization process. Moreover, empirical evidence from incremental information content test shows that the incremental value-relevance of IAS is also weakened through the accounting harmonization process. Further empirical evidence demonstrates that CAS earnings appear to substitute for CAS earnings in the valuation process to the extent to which CAS is harmonized with IAS.
\end{abstract}

Keywords Chinese Accounting Standards, International Accounting Standards, information content, accounting internationalization

摘要 以我国 $\mathrm{AB}$ 股上市公司 ( $\mathrm{A}$ 股与 $\mathrm{B}$ 股分别同时在国内、国外上市的公司) 1996 年度至 2003 年度的财务报告为研究对象, 通过比较我国会计准则与国际会计准则的 价值相关性, 检验了中国会计国际化进程所产生的效果。相对信息含量的检验结果 表明, 按国际会计准则报告的盈余的信息含量, 要强于按中国会计准则报告的盈余,

Received March 26, 2008, revised December 14, 2008

YOU Jiaxing $(\bowtie)$

Planning \& Statistics Department, School of Economics, Xiamen University, Xiamen 361005, China

E-mail: xmuyou@sina.com

LUO Shengqiang

Accounting Department, School of Management, Xiamen University, Xiamen 361005, China

E-mail: luoshengqiang@126.com 
但国际会计准则的这种相对信息含量随着中国会计国际化的进程而有所削弱。而增 量信息含量的检验结果表明, 中国会计国际化进程使得国际会计准则相对于中国会 计准则的增量信息含量也被减弱。进一步的检验结果还表明, 随着中国会计国际化 进程的步伐, 中国投资者把按两套准则报告的盈余当作替代信号, 并且更偏爱采用 按照自己熟悉的会计准则(即中国会计准则)报告的盈余数据。

关键词 中国会计准则, 国际会计准则, 信息含量, 会计国际化进程

\section{Introduction}

Differences in value relevance under various accounting standards have long been debated in the international accounting literature. Most of the previous research has concentrated on the U.S. Securities and Exchange Commission's (SEC) policy that requires firms registered outside the U.S. and listed on a primary U.S. exchange to reconcile their reported earnings and shareholders' equity to the Generally Accepted Accounting Principles in the United States (GAAP) as part of 20-F filing, regardless of the cost or difficulty of doing so. However, these reconciliations provide a good opportunity to compare the differences created by alternative accounting practices (McQueen, 1992; Bandyopadhyay et al., 1994; Barth and Clinch, 1996; Fulkerson and Meek, 1998; Gornik-Tomaszewski, Sylwia and Rozeny, 1999; Hora et al., 2003).

The application of Chinese Accounting Standards (CAS) and International Accounting Standards (IAS) for the same listed company in China's B-share market has also provided an interesting setting to compare the usefulness between CAS and IAS. Many scholars have compared the value-relevance of accounting information between CAS and IAS from different perspectives (Haw et al., 1998; Bao and Chow, 1999; Abdel-khalik et al., 1999; Eccher and Healy, 2000).

However, previous studies have provided inconclusive evidence due to data from different years and various valuation models. This study attempts to investigate the value-relevance ${ }^{1}$ of accounting information based on CAS and IAS from the perspective of relative information content and incremental information content, and tends to focus on the effect of accounting internationalization process in China. Also, since prior research has failed to take into consideration the interaction effects between accounting information based

\footnotetext{
${ }^{1}$ Value relevance in this study is measured by the ability of financial statement information to capture or summarize information that affects share values, and is constructed by the statistical association between accounting information and market values or returns over a long window, consistent with the value relevance used by Francis and Schipper (1999).
} 
on CAS and IAS, we attempt to investigate complementary or substitution effects that may exist between CAS and IAS earnings.

In general, based on financial reports of AB-share listed companies in China from 1996 to 2003, we find unexpected earnings reported under IAS have more information content to A-share investors than those under CAS. However, the relative value-relevance of IAS is weakened through accounting internationalization process in China. We also find that the incremental value-relevance of IAS is also weakened through the accounting harmonization process. Finally, we find that CAS earnings appear to substitute for CAS earnings in the valuation process to the extent to which CAS is harmonized with IAS. Because China has become the world's largest transitional economy and emerging capital market, evidence presented in this study has important implications for those developing countries and transitional economies which are striving to harmonize and integrate their domestic accounting standards with IAS or GAAP which is based on developed economic environment and mature capital markets.

This study contributes to the international accounting literature in the following ways. First, to date, this study is the first one to systematically and comprehensively compare value relevance between CAS and IAS based on relative and incremental information content tests, given the fact that conflicting evidence was provided by previous research. Second, in the past two decades, China has made great progress in harmonizing its accounting standards with IAS. This study investigates the change of value relevance between CAS and IAS in order to evaluate the effects of accounting internationalization process in China. Finally, this study discusses the effect of interaction between two set of accounting earnings under different accounting standards on Chinese investors' investment decisions.

The remainder of the study is organized as follows. Section 2 discusses capital market and accounting internationalization process in China. Literature review is provided in Section 3. Section 4 presents research questions in the context of Chinese special institution background. The research design is outlined in Section 5. Section 6 describes data sources and descriptive statistics. Empirical results and related analysis are presented in Section 7. The last section summarizes and concludes this paper with key findings.

\section{Capital markets and accounting internationalization process in China}

\subsection{Development of capital markets in China}

In the early 1990s, the Shanghai Stock Exchange and Shenzhen Stock Exchange 
were successfully established by the Chinese government as a vehicle to transit its socialist planned economy into a market-oriented one. The establishment of those two stock exchanges has played an instrumental role in promoting corporatization of state-owned enterprises. Many state-owned enterprises, once production units in the centrally planned economy instead of legal entities separated from the state, were then restructured into companies with limited liabilities or joint-stock firms. Some of them issued shares to the public by getting listed on the two stock exchanges.

In capital markets, some Chinese listed companies which have issued A-shares to domestic investors are also authorized to issue B-shares denominated in foreign currencies to foreign investors including investors from Hong Kong, Taiwan and Macau in order to absorb foreign investment. In accordance with related regulations in China, listed companies should adopt domestic accounting standards and systems, and invite Chinese local CPAs with practice qualifications for auditing. Companies which issued B-shares are also required to restate their financial statements according to IAS or Hong Kong Accounting Standards, and give an item-by-item explanation to the resulting differences between two sets of accounting earnings, and invite overseas CPA firms for auditing and rechecking in order to increase the confidence of foreign investors in the quality of the financial reports. Such summarized reconciliations between the two sets of accounting earnings are required to be disclosed along with the Chinese GAAP-based statements in local newspapers.

\subsection{Accounting internationalization process in China}

The present Chinese accounting standards and practices evolve from a Russian style macro-oriented accounting system adopted by China in the 1950s (Tang et al.,1996). Such an old accounting standard characterized by rigid and uniform accounting systems was designed to meet the needs of a planned economy, and accordingly focused on whether the production goals of state-owned enterprises and their financial and costs plan were being met. However, since the 1980s, China opened its doors to foreign investment as a result of the economic reforms and endeavored to reach out to the international community and gain greater access to the latest technologies and the world's capital markets. During the process of transforming itself from a centrally planned economy to a market-oriented economy, China has realized the importance of a sound financial infrastructure and has thus committed itself to align its accounting practices with internationally accepted practices, especially with IAS.

Economic reforms, particularly the reform of state-owned enterprise and development of domestic capital markets have profoundly changed the accounting environment in China, resulting in the harmonization of CAS with 
IAS. The most significant change in Chinese accounting harmonization was catalyzed by the "Accounting Standards for Business Enterprises", China's accounting conceptual framework, which was promulgated in 1992 and came into effect on July 1, 1993. This conceptual framework, which governs all enterprises in China, has essentially transformed China's accounting from the traditionally rigid and uniform system into a predominately Anglo-Saxon approach to financial reporting (Xiang, 1998).

In Chinese accounting harmonization process, it is notable that some special sets of accounting standards were promulgated only for share-issuing companies. ${ }^{2}$ As a response to the experiment of incorporating state-owned enterprises and rapid development of stock markets, a special accounting system, known as the "Accounting System for Pilot Enterprises Implementing the Shareholding System", was promulgated by the Ministry of Finance (MOF) of China in 1992 in order to standardize accounting practice and disclosure by listed companies. This system, along with its amendments and attachments issued in the following years, has widely regarded as the part of Chinese GAAP that is closest to IAS (Yang and Yang, 1998). However, these pronouncements were still found to have material differences with comparable IAS, such as the restrictions in making provision for doubtful debts and obsolete inventories.

To further move CAS in line with IAS, the MOF issued the "Accounting System for Joint-stock Companies" in replacement of the "Accounting System for Pilot Enterprises Implementing the Shareholding System" in 1998. This accounting system sets out prescribed formats for financial statements and a number of supplementary statements and is very close to comparable IAS in major items. The success of the 1998 regulation in harmonizing Chinese GAAP with IAS was well recognized both inside and outside China (Chen et al., 2002).

On January 1, 2001, a new comprehensive "Accounting System for Business Enterprises" was promulgated by MOF in 2000 to replace the old "Accounting System for Joint-stock Companies", significantly enhancing the comparability and relevance of Chinese enterprises' financial statements and pushing Chinese accounting practice further in the direction of international standards.

\section{Literature review}

In the area of international accounting, researchers empirically compare the value relevance of foreign GAAP versus U.S. GAAP using foreign companies listed in the U.S. market (McQueen, 1992; Bandyopadhyay et al., 1994; Barth and Clinch,

${ }^{2}$ This study only focuses on accounting international harmonization for Chinese listed companies. 
1996; Fulkerson and Meek, 1998; Gornik-Tomaszewski and Rozeny, 1999; Hora et al., 2003). While not conclusive, the findings from much of the previous research on evaluation of the value relevance of Form 20-F filing tended to suggest that accounting numbers based on foreign accounting standards have information content. However, the findings on the value relevance of reconciliation disclosure required by the U.S. SEC were inconsistent.

Following this line, many researchers compare Chinese GAAP-based information with IAS-based information in Chinese capital market. Chinese capital market is divided into the A-share market targeting domestic investors and B-share market targeting overseas investors. In line with such special market segmentation, comparison of value relevance between CAS and IAS should be made from A-share investors' and B-share investors' viewpoints. ${ }^{3}$

Although China has made remarkable progress in accounting internationalization in the past decade, many existing factors still exert adverse influences on the accounting information environment in China. First, the overwhelming majority of listed companies were originally formed from stated-owned enterprises, and Chinese government has normally retained a majority ownership in these listed companies after their initial public offering. As a result, there are many incentives for the government as controlling shareholders to intervene in these companies, thus impairing the quality of financial reports. Second, supporting infrastructure for CAS, including corporation governance, internal monitoring, independent auditing, and other enforcement mechanisms, is under development so as not to ensure production and dissemination of high-quality accounting information. Third, the newly corporatized state-owned enterprises face political costs of government control due to government administrative interference, despite Chinese government's intensification of efforts to decrease government control in corporate governance of listed companies. Local governments often consider the number of listed companies in their jurisdictions as an important performance indicator and are motivated to help listed companies through various government subsidies when listed companies face financial difficulty (Aharnoy et al., 2000). These well-recognized factors induce many scholars to question value relevance of accounting information in Chinese capital market, resulting in one pervasive hypothesis in existing literature that value relevance is higher for accounting information based on IAS than for that based on CAS.

Some existing studies concentrate on value-relevance of accounting information to domestic investors. Chen et al. (2001) examined whether domestic investors in China's stock markets perceive accounting information based on

\footnotetext{
${ }^{3}$ It has been widely thought that liquidity in the B-share market is limited and thus its market efficiency is affected, so this study is aimed at A-share investors.
} 
Chinese GAAP to be value-relevant and report evidence consistent with the notion that accounting information is value-relevant to investors in the Chinese market in spite of the young age of the market and perception of inadequate accounting and financial reporting in China. Haw et al. (1999) investigated the value-relevance of earnings in the emerging capital market in China by examining the information content of accounting earnings measured under CAS. Results showed that earnings reported in China are value-relevant to A-share investors. Therefore, contrary to the expectations of many researchers, evidence presented has consistently shown that accounting information under CAS is value-relevant to A-share investors.

Two existing studies are devoted to investigating the value-relevance of CAS versus IAS-based accounting information to overseas investors (B-share investors) in China. However, they provided conflicting evidence. Haw et al. (1998) reported that information based on Chinese GAAP is value relevant and the reconciliation to IAS has limited value to overseas investors in the B-share market. They also found significant incremental information content of IAS reconciliation for $\mathrm{H}$-share traded at the Hong Kong Stock Exchange. Their results suggest that the same accounting information may have varying degrees of value-relevance in different markets. However, Bao and Chow (1999) examined the relative value relevance in equity valuation of two sets of accounting information of Chinese B-share listed companies and provided opposite evidence. Their findings showed that earnings and book value reported based on IAS have greater information content than those based on CAS, and the results of yearly regression analysis generally suggest that the explanatory power of these earnings and book values for share prices increase over time. They also suggested that a plausible explanation of their findings is that Chinese regulation requires a company's dividend distribution to be based on the lower profits reported in two sets of financial statements according to different accounting requirements. Since earnings based on IAS are significantly lower than those based on CAS, they are more value relevant for dividend decisions and thus more useful for equity valuation.

There are other two studies attempted to compare value-relevance between accounting information based on CAS and IAS. Abdel-khalik et al. (1999) elaborated on the differences between these two information environments and suggested that accounting earnings based on domestic accounting standards and A-share prices are not correlated while accounting earnings based on IAS and share prices are correlated for B-shares. However, to their surprise, they found that earnings and unexpected returns are correlated for A-shares yet not for B-shares. High price volatility, significant and continuing dominance of government officials, and thinness of trade in B-shares were offered as possible explanations for their findings. Eccher and Healy (2000) examined the usefulness 
of CAS and IAS to A-share investors and concluded that accounting information based on IAS is no more useful than that based on CAS. They also argued that one explanation for the failure of IAS data to dominate CAS data is the absence of effective controls and infrastructure in China to monitor the additional reporting judgment available to managers under IAS.

It can be seen from the above review that prior empirical studies, using data from different years and various valuation models, have provided inconsistent evidence that accounting information is value relevant to A-share investors in China. Researchers are typically perplexed and unwilling to accept such a result. Consequently, various interpretations and conjectures, some of which disagree with each other, have been offered in the literature.

\section{Research questions}

It is generally thought that IAS is a more conservative accounting standard than CAS, and can reflect listed companies' value more objectively (Chen et al., 2002). In most cases, accounting information based on IAS is audited by internationally recognized audit firms to assure compliance with IAS. It is thus followed that earnings under IAS are more reliable and have more information content than those based on CAS to A-share investors. In addition, distribution of dividends should be determined by referring to the lower distributable profit reported in the two sets of financial statements based on CAS and IAS. However, existing evidence shows that earnings under IAS have no more value relevance than those under CAS. Therefore, the first objective of this study is to compare relative value relevance between the two sets of earnings based on those different accounting standards.

The evidence presented previously has shown that both earnings based on CAS and those based on IAS are value relevant to A-share investors. It also suggests that the two sets of accounting standards can both reflect most information of listed companies to some degree. In that summarized reconciliations between two sets of accounting earnings are disclosed in A-share financial reporting to A-share investors, the second objective of this study is to explore whether required reconciliations to IAS have incremental information content given the fact that earnings based on CAS is value relevant to A-share investors.

Gornik-Tomaszewski and Rozeny (1999) found that foreign GAAP earnings appear to substitute for U.S. GAAP earnings in the valuation process and U.S. investors prefer to use performance indicators measured according to the familiar accounting standards. Yet previous research has failed to consider interaction 
effects between the two sets of earnings based on CAS and IAS. As a result, the third objective of this study is to make sure whether both earnings based on CAS and IAS are substitutes for, or complements of each other when Chinese A-share investors make investment decisions.

In the accounting internationalization process in China, it is widely accepted that a significant progress has been made in harmonization of CAS with IAS. The last objective of this study is to investigate the effect of the accounting internationalization process on relative information content, incremental information content and interaction effects between two sets of earnings based on CAS and IAS in order to evaluate Chinese accounting internationalization process.

\section{Research design}

As described earlier, accounting earnings based on CAS is value relevant to A-share investors, while the findings on information content of accounting earnings based on IAS are mixed. Such conflicting conclusions may result from different valuation models used by different authors. Therefore, various valuation models will be used in this study to explore information content differences between CAS and IAS and gain a more reliable result. In testing the value-relevance of accounting numbers based on their statistical association with stock prices or returns, it is important to distinguish between relative and incremental information content (Biddel and Seow, 1995). Which design should be used depends on specific research motivation and the questions we may wish to answer.

\subsection{Relative information content test}

The relative information content of GAAP alternatives is indicated by the ranking of $R^{2}$ statistics obtained from separate regressions for each GAAP regime. The relative information content of alternative measures is very useful for making choices among measurement methods for the purposes of standard setting. Similarly, the quality of different measures of the same underlying accounting construct (e.g., earning and cash flow) will be reflected in tests of relative information content.

The relative information content models are as follows:

$$
C A R_{j t}=\beta_{0}+\beta_{1} \frac{\Delta E P S_{j t}^{C A S}}{P_{j t}}+\omega_{j t}
$$




$$
C A R_{j t}=\gamma_{0}+\gamma_{1} \frac{\Delta E P S_{j t}^{I A S}}{P_{j t}}+\mu_{j t}
$$

where:

$C A R_{j t}=$ cumulative abnormal month returns for firm $j$ from May in the year $t$ to April in the year $t+1$;

$\triangle E P S_{j t}^{C A S}=$ unexpected earnings per share based on CAS for firm $\mathrm{j}$ in the year $t$, it equals the difference of earnings per share between period $t$ and $t-1$ based on CAS;

$\triangle E P S_{j t}^{I A S}=$ unexpected earnings per share based on IAS for firm $j$ in the year $t$, it equals the difference of earnings per share between period $t$ and $t-1$ based on IAS;

$P_{j t}=$ the first opening price for firm $j$ in May of year $t$.

The likelihood ratio test provided by Vuong (1989) is used in this study to compare relative information content across the two sets of earnings. ${ }^{4}$

\subsection{Incremental information content test}

Incremental information content is indicated by the additional explanatory power attributable to one measure after controlling for the information in the other measure, which may be tested by examining the $t$-statistics or partial $F$-statistic in a multiple regression including accounting measures from both GAAP alternatives. Incremental information content tests will potentially be informative for policy regarding supplementary disclosures. Although the two earnings measures may both have incremental information content, it is impossible to draw conclusions about relative information content from one incremental information test.

The incremental information content model is as follows:

$$
C A R_{j t}=\partial_{0}+\partial_{1} \frac{\Delta E P S_{j t}^{C A S}}{P_{j t}}+\partial_{2} \frac{\Delta E P S_{j t}^{I A S}}{P_{j t}}+\eta_{j t}
$$

where variables are the same as those defined in Model (1) and (2).

\subsection{Simultaneous alternative signals approach}

Whereas prior research has not considered the interactions among different

\footnotetext{
${ }^{4}$ Explanations and computation procedures of Vuong (1989) test are provided in detail by Dechow (1994).
} 
accounting earnings based on different accounting standards, which may affect the inferences on the incremental information content of reconciliation, this study adopts the simultaneous alternative signals approach used by Eichenseher et al. (1991) to test value relevance of alternative income signals measured under the historical cost and current cost conventions.

The simultaneous alternative signals approach recognizes complementary or substitution effects that may exist between earnings based on CAS and those based on IAS. In the context of information content, whenever alternative earnings measurements are substitutes for, or complements of each other, the marginal effect of one variable on stock returns will depend on the value of the other.

In the proposed method of this study, if two earnings signals are complements of one another, increases in earnings based on IAS accompanied by increases in those based on CAS will result in higher market prices revisions than would be observed if two signals are independent. On the other hand, if two earnings signals are substitutes for one another, increases in earnings based on IAS accompanied by increases in those based on CAS will result in lower market prices revisions than would be observed if they are independent.

The above hypotheses are tested by estimation of the following model.

$$
\begin{aligned}
C A R_{j t}= & \beta_{0}+\beta_{1} \frac{\Delta E P S_{j t}^{C A S}}{P_{j t}}+\beta_{2} \frac{\Delta E P S_{j t}^{I A S}}{P_{j t}}+\beta_{3} D_{1} \frac{\Delta E P S_{j t}^{C A S}}{P_{j t}} \frac{\Delta E P S_{j t}^{I A S}}{P_{j t}} \\
& +\beta_{4} D_{2} \frac{\Delta E P S_{j t}^{C A S}}{P_{j t}} \frac{\Delta E P S_{j t}^{I A S}}{P_{j t}}+\varepsilon_{j t}
\end{aligned}
$$

where:

$$
\begin{aligned}
& D_{1}=1, \text { when } \triangle E P S_{j t}^{C A S}>0 \text { and } \triangle E P S_{j t}^{I A S}>0 ; \text { otherwise } 0 \\
& D_{2}=1 \text {, when } \triangle E P S_{j t}^{C A S} \leqslant 0 \text { and } \triangle E P S_{j t}^{I A S} \leqslant 0 ; \text { otherwise } 0 .
\end{aligned}
$$

Other variables are defined as the same as those in the above models.

When $\triangle E P S_{j t}^{C A S}>0$ and $\triangle E P S_{j t}^{L A S}>0$, a negative value of $\beta_{3}$ will mean that $\triangle E P S_{j t}^{C A S}$ and $\triangle E P S_{j t}^{I A S}$ are substitutes of eath other, while a positive value of $\beta_{3}$ will suggest that they are complements of eath other. In contrast, when $\triangle E P S_{j t}^{C A S} \leqslant 0$ and $\triangle E P S_{j t}^{L A S} \leqslant 0$, a negative value of $\beta_{3}$ will mean that $\triangle E P S_{j t}^{C A S}$ and $\triangle E P S_{j t}^{I A S}$ are complements of eath other, while a positive value of $\beta_{3}$ will suggest that they are substitutes of eath other.

The other two situations $\left(\triangle E P S_{j t}^{C A S} \geqslant 0\right.$ and $\triangle E P S_{j t}^{I A S} \leqslant 0 ; \triangle E P S_{j t}^{C A S} \leqslant 0$ 
and $\left.\triangle E P S_{j t}^{I A S} \geqslant 0\right)$ are not considered in this study because they are rarely observed in the collected data, and the directions of the relationship between the independent variables and the dependent variable could not be determined in those two situations.

\section{Sample and descriptive statistics}

This study covers an 8-year period between 1996 and 2003. Two sets earnings based on CAS and IAS for those listed companies which issued A-shares and B-shares are searched from their A-share annual financial reports. This study excludes those which do not disclose conciliations to IAS or whose related information cannot be collected, and the search yields 430 observations. Other financial data come from the Wind Database.

Because the sample consists of time series observations on each of several cross-sectional units, we apply period-fixed panel data model to control for fixed effects of calendar years and/or economies. Table 1 presents descriptive statistics of all the variables used in this study.

Table 1 Descriptive statistics

\begin{tabular}{lrcccc}
\hline Full sample & $C A R$ & $E P S^{C A S}$ & $E P S^{I A S}$ & \multicolumn{1}{c}{$\Delta E P S^{C A S}$} & \multicolumn{1}{c}{$\Delta E P S^{I A S}$} \\
\hline Mean & 0.060 & 0.017 & 0.014 & -0.002 & 0.001 \\
Median & -0.030 & 0.014 & 0.011 & -0.001 & -0.001 \\
Std. Dev. & 0.388 & 0.079 & 0.080 & 0.082 & 0.078 \\
Maximum & 2.315 & 0.352 & 0.354 & 0.630 & 0.562 \\
Minimum & -0.629 & -0.704 & -0.703 & -0.560 & -0.538 \\
$N$ & 430 & 430 & 430 & 430 & 430 \\
\hline
\end{tabular}

\section{Empirical results and analysis}

\subsection{Pearson correlation coefficients analysis}

In order to have a general understanding of relationship between various variables, Pearson correlation coefficients analysis is made before estimating regression models. The results are presented in Table 2, showing that two sets of unexpected earnings based have a positive relationship with annual abnormal returns on A-shares, and they are positively correlated with each other. The Pearson correlation coefficient amounts to 0.913 , suggesting that both sets of earnings can reflect most of the common financial information from listed companies. 
Table 2 Pearson correlation coefficients matrix

\begin{tabular}{|c|c|c|c|c|c|}
\hline & $C A R_{j t}$ & $E P S^{C A S}$ & $E P S^{I A S}$ & $\Delta E P S^{C A S}$ & $\triangle E P S^{I A S}$ \\
\hline$C A R_{j t}$ & 1 & $0.215^{* * *}$ & $0.210^{* * *}$ & $0.207^{* * *}$ & $0.214^{* * *}$ \\
\hline$E P S^{C A S}$ & $0.215^{* * *}$ & 1 & $0.978^{* * *}$ & $0.509^{* * *}$ & $0.496^{* * *}$ \\
\hline$E P S^{I A S}$ & $0.210^{* * *}$ & $0.978^{* * *}$ & 1 & $0.923^{* * *}$ & $0.525^{* * *}$ \\
\hline$\triangle E P S^{C A S}$ & $0.207^{* * *}$ & $0.509^{* * *}$ & $0.923^{* * *}$ & 1 & $0.913^{* * *}$ \\
\hline$\Delta E P S^{I A S}$ & $0.214^{* * *}$ & $0.496^{* * *}$ & $0.525^{* * *}$ & $0.913^{* * *}$ & 1 \\
\hline
\end{tabular}

Note: ${ }^{*},{ }^{* *}$, and ${ }^{* * *}$ indicate significant at the $10 \%, 5 \%$, and $1 \%$ levels, respectively (two-tailed). The same in tables below.

\subsection{Regression results from relative information content test ${ }^{5}$}

Besides estimating regression models for pooled cross-section and time-series sample, we divide the whole sample period into three stages, namely the first stage when "Accounting System for Pilot Enterprises Implementing the Shareholding System" was implemented (1996-1997), the second stage when "Accounting System for Joint-stock Companies" was implemented (1998-2000), and the third stage when "Accounting System for Business Enterprises" was implemented (2001-2003), in accordance with respective accounting internationalization stages in China to explore the effect of accounting internationalization process in China on value relevance of CAS and IAS.

Table 3 presents regression results from relative information content test and documents two interesting findings related to our first research question. First, overall results for full sample show that earnings based on CAS and those based on IAS are both significant at $1 \%$ level, and suggest that both of them have information content to A-share investors. In respect of relative information content, adjusted $R^{2}$ of model (1) is bigger than that of model (2), but the result of Vuong test (Vuong, 1989) shows that it is not statistically significant, suggesting that earnings based on IAS has no more value relevance than those based on CAS.

Table 3 Regression results from relative information content test

\begin{tabular}{|c|c|c|c|c|c|c|c|c|}
\hline \multirow[t]{2}{*}{ Variables } & \multicolumn{2}{|c|}{ Full sample } & \multicolumn{2}{|c|}{ The first stage } & \multicolumn{2}{|c|}{ The second stage } & \multicolumn{2}{|c|}{ The third stage } \\
\hline & (1) & (2) & (3) & (4) & (5) & (6) & (7) & (8) \\
\hline \multirow[t]{2}{*}{ Intercept } & $0.054^{* * *}$ & $0.057^{* * *}$ & 0.008 & 0.012 & $0.262^{* * *}$ & $0.264^{* * *}$ & $-0.113^{* * *}$ & $-0.111^{* * *}$ \\
\hline & $(2.982)$ & (3.154) & $(0.242)$ & $(0.344)$ & $(8.150)$ & $(8.213)$ & $(-6.994)$ & $(-6.841)$ \\
\hline$\Delta E P S_{j t}^{L A S}$ & $1.054^{* * *}$ & & $2.213^{* *}$ & & $2.262^{* * *}$ & & $0.563^{* * *}$ & \\
\hline$P_{j t}$ & $(4.532)$ & & $(2.482)$ & & $(4.373)$ & & $(3.322)$ & \\
\hline
\end{tabular}

(To be continued)

\footnotetext{
${ }^{5}$ Because the Vuong test (Vuong, 1989) requires that the tested model should perform ordinary least squares regression, we did not apply panel data model in this regression.
} 


\begin{tabular}{|c|c|c|c|c|c|c|c|c|}
\hline \multirow[t]{2}{*}{ Variables } & \multicolumn{2}{|c|}{ Full sample } & \multicolumn{2}{|c|}{ The first stage } & \multicolumn{2}{|c|}{ The second stage } & \multicolumn{2}{|c|}{ The third stage } \\
\hline & $(1)$ & (2) & (3) & (4) & $(5)$ & (6) & $(7)$ & $(8)$ \\
\hline$\triangle E P S_{j t}^{C A S}$ & & $0.965^{* * *}$ & & $0.985^{*}$ & & $2.078^{* * *}$ & & $0.471^{* * *}$ \\
\hline$\overline{P_{j t}}$ & & (4.392) & & (1.773) & & $(4.281)$ & & $(2.811)$ \\
\hline $\operatorname{Adj}-R^{2}$ & 0.044 & 0.041 & 0.090 & 0.039 & 0.094 & 0.091 & 0.047 & 0.033 \\
\hline F value & $20.503^{* * *}$ & $19.242^{* * *}$ & $6.173^{* *}$ & $3.124^{*}$ & $19.112^{* * *}$ & $18.363^{* * *}$ & $11.003^{* * *}$ & $7.912^{* * *}$ \\
\hline$N$ & 430 & 430 & 54 & 54 & 178 & 178 & 203 & 203 \\
\hline $\begin{array}{l}\text { Adj- } R^{2} \\
\quad \text { increme- } \\
\text { ntal }(\%)\end{array}$ & \multicolumn{2}{|c|}{0.27} & \multicolumn{2}{|c|}{5.13} & \multicolumn{2}{|c|}{0.35} & \multicolumn{2}{|c|}{1.42} \\
\hline $\begin{array}{l}Z \text { value of } \\
\text { Vuong } \\
\text { test }\end{array}$ & \multicolumn{2}{|c|}{1.193} & \multicolumn{2}{|c|}{$1.885^{*}$} & \multicolumn{2}{|c|}{0.886} & \multicolumn{2}{|c|}{$1.877^{*}$} \\
\hline
\end{tabular}

Second, regression results by stages show that value relevance of both sets of earnings based on CAS and IAS were enhanced after implementation of the "Accounting System for Joint-stock Companies" and weakened after implementation of the "Accounting System for Business Enterprises". In respect of change of relative information content in accounting internationalization process, regression results at the first stage indicate that earnings based on IAS had more information content than those based on CAS when the "Accounting System for Pilot Enterprises Implementing the Shareholding System" was implemented, but regression results at the second stage show that earnings based on IAS had no more information content than those based on CAS, suggesting that implementation of the "Accounting System for Joint-stock Companies" greatly strengthened value relevance of CAS. However, regression results at the third stage indicate that earnings based on IAS had more information content than those based on CAS, suggesting implementation of the "Accounting System for Business Enterprises" did not improve value relevance of CAS relative to IAS. Overall, relative information content of IAS has been decreasing, because its incremental adjusted $R^{2}$ decreased from $5.13 \%$ of the first stage to $1.42 \%$ of the third stage.

\subsection{Regression results from incremental information content test}

Regression results from incremental information content test are presented in Table 4. Overall results for full sample show that coefficients of the two sets of earning measures are positive (but not statistically significant), suggesting that both of them have no incremental information content to each other. Regression results by stages indicate that, in comparison with those based on CAS, earnings based on IAS have significant incremental information content after implementation of the "Accounting System for Experimental Joint-stock 
Companies". However, the significance disappeared after implementation of the "Accounting System for Joint-stock Companies" and appeared again after implementation of the "Accounting System for Business Enterprises".

Table 4 Regression results from incremental information content test

\begin{tabular}{lcccc}
\hline Variables & Full sample & The first stage & The second stage & The third stage \\
& $(1)$ & $(2)$ & $(3)$ & $(4)$ \\
\hline Intercept & -0.041 & 0.011 & $0.239^{* * *}$ & -0.034 \\
& $(-1.272)$ & $(0.326)$ & $(6.016)$ & $(-1.453)$ \\
$\frac{\Delta E P S_{j t}^{I S S}}{P_{j t}}$ & 0.642 & $1.933^{*}$ & 0.485 & $0.831^{*}$ \\
$\frac{\Delta E P S_{j t}^{C A S}}{P_{j t}}$ & $(1.60)$ & $(1.732)$ & $(0.494)$ & $(1.774)$ \\
$R^{2}$ & 0.071 & 0.288 & 0.573 & -0.318 \\
$F$ value & $(0.194)$ & $(0.424)$ & $(0.623)$ & $(-0.704)$ \\
$N$ & 0.539 & 0.076 & 0.546 & 0.128 \\
& $74.941^{* * *}$ & $3.124^{*}$ & $83.184^{* * *}$ & $8.193^{* * *}$ \\
\hline
\end{tabular}

7.4 Regression results from simultaneous alternative signals approach

Regression results from simultaneous alternative signals approach are presented in Table 5. Overall results for full sample show that the coefficient of $D_{1} \frac{\Delta E P S_{j t}^{C A S}}{P_{j t}} \frac{\Delta E P S_{j t}^{I A S}}{P_{j t}}$ is significantly negative at $1 \%$ level, and the coefficient of $D_{2} \frac{\Delta E P S_{j t}^{C A S}}{P_{j t}} \frac{\Delta E P S_{j t}^{I A S}}{P_{j t}}$ is significantly positive at $1 \%$ level, suggesting that unexpected earnings based on IAS and those based on CAS are used by A-share investors as substitutes rather than as complements.

Table 5 Regression results from simultaneous alternative signals approach

\begin{tabular}{lcccc}
\hline \multicolumn{1}{c}{ Variables } & Full sample & The first stage & The second stage & The third stage \\
& $(1)$ & $(2)$ & $(3)$ & $(4)$ \\
\hline Intercept & $-0.052^{*}$ & 0.019 & $0.235^{* * *}$ & $-0.050^{*}$ \\
& $(-1.628)^{* * *}$ & $(0.472)$ & $(5.893)$ & $(-1.872)^{* * *}$ \\
$\frac{\Delta E P S_{j t}^{I A S}}{P_{j t}}$ & $1.231^{* * *}$ & 1.994 & 0.708 & $1.324^{* * *}$ \\
$\frac{\Delta E P S_{j t}^{C A S}}{P_{j t}}$ & $(2.864)$ & $(1.043)$ & $(0.642)$ & $(2.837)$ \\
$D_{1} \frac{\Delta E P S_{j t}^{C A S}}{P_{j t}} \frac{\Delta E P S_{j t}^{L A S}}{P_{j t}}$ & $\left(-2.578^{* * *}\right.$ & -5.302 & 0.655 & 0.507 \\
\hline
\end{tabular}


(Continued)

\begin{tabular}{lcccc}
\hline \multicolumn{1}{c}{ Variables } & Full sample & The first stage & The second stage & The third stage \\
& $(1)$ & $(2)$ & $(3)$ & $(4)$ \\
\hline \multirow{2}{*}{$D_{2} \frac{\Delta E P S_{j t}^{C A S}}{P_{j t}} \frac{\Delta E P S_{j t}^{L A S}}{P_{j t}}$} & $3.355^{* * *}$ & -5.242 & 10.156 & $3.476^{* * *}$ \\
$R^{2}$ & $(3.492)$ & $(-0.273)$ & $(1.392)$ & $(3.723)$ \\
$F$ value & 0.553 & 0.043 & 0.554 & 0.196 \\
$N$ & $76.043^{* * *}$ & 1.584 & $82.574^{* * *}$ & $7.314^{* * *}$ \\
\hline
\end{tabular}

Regression results by stages indicate that substitute effect between unexpected earnings based on IAS and those based on CAS was not significant when Chinese listed companies implemented "Accounting System for Pilot Enterprises Implementing the Shareholding System" and "Accounting System for Joint-stock Companies" (from 1996 to 2000). However, such substitute effect became significant after the "Accounting System for Business Enterprises" was implemented in 2001, suggesting that A-share investors began to recognize that both sets of unexpected earnings based on CAS and IAS are effectively equivalent in the valuation process, although unexpected earnings based on IAS still have relative and incremental value relevance compared with those based on CAS as indicated by the above findings from relative and incremental information content test after 2001. A possible explanation for such a finding is that understanding of IAS would be time-consuming to A-share investors for most of who are not familiar with IAS.

\section{Conclusions and implications}

This study concentrates on the effect of accounting internationalization process in China by comparing value-relevance between CAS and IAS from relative information content and incremental information content test. Based on standard assumptions about the association between returns and earnings, this study uses the first differences as proxies for unexpected earnings and applies the simultaneous alternative accounting signals approach.

Results of this study from relative information content test indicate that unexpected earnings based on IAS have more information content than those based on CAS, but such relative information content of IAS was weakened through Chinese accounting internationalization process.

Findings from incremental information content test show that the two sets of unexpected earnings based on IAS and CAS have no incremental information content to each other on the whole. Unexpected earnings based on IAS have significant incremental information content relative to those based on CAS at the 
first stage when listed companies adopted the "Accounting System for Pilot Enterprises Implementing the Shareholding System"; Incremental information content of IAS ceased to remain significant after the "Accounting System for Joint-stock Companies" was implemented. However, incremental information content of IAS became significant again after implementation of the "Accounting System for Business Enterprises".

Results from simultaneous alternative signals approach indicate that unexpected earnings based on IAS appear to substitute for those based on CAS in the A-share investors' valuation process. Such substitute effect between them was not significant at the first and second stage (from 1996 to 2000). But the effect became significant after the "Accounting System for Business Enterprises" was implemented in 2001.

Empirical evidence presented above suggests that Chinese accounting internationalization process does enhance value relevance of CAS relative to IAS. However, it is important to note that after implementation of the "Accounting System for Business Enterprises" in 2001, the value relevance of CAS has not been improved compared with that of IAS, despite the fact that A-share investors began to substitute unexpected earnings based on IAS for those based on CAS. One important reason contributing to such a result is that CAS after 2001 has left accountants and managers more latitude in making judgments on the accounting choice than ever before. In Chinese accounting internationalization process, higher level of flexibility has been granted to managers under CAS, but adequate supporting infrastructure of CAS which is necessary for the production and dissemination of high-quality accounting information has not kept pace with such a process. If a significant degree of accounting choice is available to management, the alignment of management and equity investors becomes an important consideration in determining whether flexibility in accounting choice will be used by management for signaling to the equity market, or to manipulate numbers in their own self-interest (Pope, 1993).

Much evidence shows that many Chinese institutional factors force management of listed companies to manipulate accounting earnings under CAS in their own self-interest. First, the controlling shareholders of many Chinese listed companies are either state-owned enterprises or government agencies, both of which depend heavily on earnings under CAS to evaluate performance of listed companies' management. The tenure, promotion, and political future of top management count on earning performance in the eyes of controlling shareholders (De Fond et al., 2000; Xiao et al., 2000). Second, many listed companies run into financial difficulties soon after initial public offering, creating urgent incentives to improve the bottom-line earnings (Aharnoy, Lee and Wong, 2000). Third, Chinese security regulations contain explicit 
profitability targets that govern the eligibility for raising additional capital through rights offering or determining delisting status, resulting in strong incentives for earnings management (Chen et al., 2001; DeFond et al., 2000). Finally, a documented lack of high quality auditing may further exacerbate earnings management (DeFond et al., 2000; Xiang, 1998). Therefore, it seems that flexibility allowed for by CAS after 2001 was abused by top managers of listed companies to manipulate their accounting earnings based on CAS given the lack of effective supporting infrastructure.

Acknowledgements We thank Katherine Schipper, Agnes Cheng, Sun Qian and two anonymous referees for extensive comments. This research is supported by the National Natural Science Foundation of China (No. 70632001), the Social Science Foundation of Ministry of Education, China (No. 07JJD630009, 08JC630073), and the Social Science Foundation of Fujian province (No. 2008C012).

\section{References}

Aharnoy J, Lee J C, Wong T J (2000). Financial packaging of IPO firms in China. Journal of Accounting Research, 38: 103-126

Abdel-khalik A R, Wong K A, Wu A (1999). The information environment of China's A and B shares: Can we make sense of the numbers? The International Journal of Accounting, 34(4): 467-489

Bandyopadhyay S P, Hanna J D, Richardson G (1994). Capital markets effects of U.S.-Canada GAAP differences. Journal of Accounting Research, 32: 262-277

Bao B H, Chow L (1999). The usefulness of earnings and book value for equity valuation in emerging capital markets: Evidence from listed companies in the People's Republic of China. Journal of International Financial Management and Accounting, 10: 85-104

Barth M, Clinch G (1996). International accounting differences and their relation to share prices: Evidence from U.K., Australian, and Canadian firms. Contemporary Accounting Research,13: 134-170

Biddle G, Seow G, Siegel A (1995). Relative versus incremental information content. Contemporary Accounting Research, 12: 1-23

Charles J P, Chen Shimin, Su Xijia (2001). Profitability regulation, earnings management, and modified audit opinions: Evidence from China. Auditing: a Journal of Practice and Theory, 20(2): 9-30

Charles J P, Chen Shimin, Su Xijia, Wang Yuetang (2004). Incentives for and consequences of initial voluntary asset write-downs in the emerging Chinese market. Journal of International Accounting Research, 3(1): 43-61

Chen C J P, Gul F A, Su X (1999). A comparison of reported earnings under Chinese GAAP vs. IAS: Evidence from the Shanghai stock exchange. Accounting Horizons, 13(2): 91-111

Dechow P (1994). Accounting earnings and cash flows as measures of firm performance: The role of accounting accruals. Journal of Accounting and Economics, 18: 3-42

DeFond M L, Wong T J, Li S (2000). Improved auditor independence and the flight from audit quality: The Chinese experience. Journal of Accounting and Economics, 28: 269-305

Eccher E P, Healy M (2000). The role of international accounting standards in transitional 
economies. Working Paper, MIT Sloan School of Management and Harvard Business School

Eichenseher J W, Lobo G J, Tung S S (1991). Interaction between alternative income measures. Journal of Business Research, 22: 47-63

Easton P D, Trevor H S (1991). Earnings as explanatory variable for returns. Journal of Accounting Research, 29(1): 19-36

Francis J, Schipper K (1999). Have financial statements lost their relevance? Journal of Accounting Research, 37: 319-352

Fulkerson C L, Meek G K (1998). Analysts' earnings forecasts and the value relevance of 20-F reconciliations from non-U.S. to U.S. GAAP. Journal of International Financial Management and Accounting, 9(1): 1-15

Gornik-Tomaszewski S, Rozeny E S (1999). Pricing of foreign GAAP earnings in U.S. capital market prior to the SEC required reconciliation disclosure. The International Journal of Accounting, 34: 539-556

Haw I M, Qi D, Wu W (1998). Value-relevance of financial reporting disclosures in an emerging capital market: The case of B-shares and H-shares in China. Working paper, The Chinese University of Hong Kong

Haw I M, Qi D, Wu W (1999). Value relevance of earnings in an emerging capital market: The case of A-shares in China. Pacific Economic Review, 4(3): 337-347

Hora J A, Tondkar R H, McEwen R A (2003). Effect of foreign GAAP earnings and Form 20-F reconciliations on revisions of analysts' forecasts. The International Journal of Accounting, 38: 71-93

McQueen P D (1992). The information content of foreign GAAP earnings and shareowners' equity and the U.S. GAAP reconciliation disclosures in SEC Form 20-F. Unpublished doctoral dissertation, New York University

Pope P F (1993). Discussion of a comparison of the value-relevance of U.S. versus non-U.S. GAAP accounting measures using Form 20-F reconciliations. Journal of Accounting Research, supplement: 265-275

Chen Shimin, Sun Zheng, Wang Yuetang (2002). Evidence from China on whether harmonized accounting standards harmonize accounting practices. Accounting Horizons, 16(3): 183-197

Chen Shimin, Sun Zheng, Wang Yuetang (2004). Evidence from China on the value relevance of operating income vs. below-the-line items. The International Journal of Accounting, 39: 339-364

Tang Y, Chow L, Cooper B (1996). Accounting and Finance in China: A Review of Current Practice ( $3^{\text {rd }}$ edition). Hong Kong: Pearson Professional

Vuong Q (1989). Likelihood ratio tests for model selection and non-nested hypotheses. Econometrica, 57: 307-333

Xiang B (1998). Institutional factors influencing China's accounting reforms and standards. Accounting Horizons, (June): 105-119

Yang J, Yang J (1998). The Handbook of Chinese Accounting. NY: Oxford University Press 